\title{
Editorial
}

\section{Panorama de la formación académica de los psicólogos en Colombia}

\author{
Julio César Ossa \\ Universidad de San Buenaventura Cali (Colombia) \\ Rebeca Puche-Navarro \\ Corporación Niñez y Conocimiento (Colombia)
}

Ossa, J. C., \& Puche-Navarro, R. (Ed). (2015). Panorama de la formación académica de los psicólogos en Colombia. Revista Cientifica Guillermo de Ockham, 13(1), 7-17.

Dedicamos este editorial a la psicología, porque entendemos el papel fundamental que desempeña en el bienestar de una sociedad, sobre todo en un contexto como el nuestro, socavado por un conflicto armado largamente asentado. Si bien en la actualidad la psicología colombiana goza de buena salud, hay algunos signos inquietantes que valdría la pena tener en cuenta. Lo uno y lo otro se pueden deducir fácilmente de las cifras que arroja su evolución.

En 1948 fue creado el primer programa académico de psicología en Colombia: el Instituto de Psicología Aplicada, fundado en la Universidad Nacional y dirigido por Mercedes Rodrigo (Ardila, 1993). En 1962, aparece el programa de Psicología de la Pontifica Universidad Javeriana de Bogotá y el programa de Consejería Psicológica de la Universidad del Valle en Cali, y en 1971 -casi diez años después- se crean los programas de psicología de la Universidad de los Andes y el plan de la Universidad del Norte de Barranquilla.

Por otra parte, se pueden identificar claramente tres períodos en el desarrollo de la psicología colombiana. El primero tiene que ver con el fortalecimiento de la carrera (1948-1991), el segundo con el crecimiento expansivo de los planes de estudio en el territorio nacional (1992-2003), y el tercero con el periodo de asentamiento (2004-2015).

En relación con la primera fase, en la década de 1970 se instituyen seis nuevos programas de psicología, lo que demuestra una mayor presencia de esta disciplina en Colombia. Los debates académicos que tuvieron lugar en las diferentes convenciones, se caracterizaron por la defensa acérrima por parte de sus representantes, de las múltiples posiciones teóricas circunscritas a determinadas orientaciones psicológicas, manifestada en fuertes enfrentamientos entre conductistas, psicoanalistas y cognitivistas, entre otros.
A mediados de la década de los ochenta, el número de programas de psicología asciende a catorce. En 1984, buena parte del colectivo de psicólogos colombianos asiste al simposio ¿Es posible una psicología unificada?, cuyo objetivo - de acuerdo con Vasco (1984) - era "[...] discernir las ventajas comparativas entre dos o más teorías que versen sobre la misma regularidad observable" (p. 195). Como es de conocimiento general, este propósito simplificador no obtuvo resultado alguno (las teorías psicológicas no fueron atravesadas por la navaja de Ockham) y en su lugar se importa una miscelánea de escuelas psicológicas cada una con su vertiente teórica, sus marcos conceptuales y sus metodologías claramente diferenciadas.

El auge y crecimiento de los programas de psicología no es particular; más bien resulta ilustrativo de una situación que atañe a toda la universidad colombiana. Los cambios en la década de los setenta corresponden a procesos de modernización de un país ávido de un proyecto universitario sólido que responda a sus necesidades. Se trata de una nación que vive un proceso de urbanización acelerado y es blanco de reformas estatales tendientes a la modernización (Melo, 1985; Uricochea, 1991). En este contexto, el crecimiento de la psicología es, simplemente, un caso ilustrativo de ese proceso global.

El segundo periodo se relaciona con el crecimiento expansivo de los planes de estudio en el territorio nacional. Entre 1992 y 2003 se pasa de dieciséis a noventa y ocho programas, crecimiento considerado como el mayor que haya tenido la psicología académica en Colombia.

La tercera etapa experimenta cierta estabilización en cuanto a la creación de nuevos programas de pregrado. Entre el 2003 y el 2014 solo fueron creados veintinueve, lo que marca una notoria diferencia con respecto al periodo 
anterior. Aunque en el segundo periodo se había iniciado el surgimiento de los programas de posgrado, es en este último cuando se consolidan.

Ahora bien, en la actualidad, ¿qué se puede afirmar acerca de la formación académica de los psicólogos en Colombia? Empecemos con algunas cifras respecto de la oferta de programas de formación. De acuerdo con el Sistema Nacional de Información de Educación Superior (SNIES, 2015), Colombia cuenta con 129 programas de pregrado en psicología y 116 de posgrado.

El paisaje académico de la psicología en Colombia muestra que buena parte de la educación universitaria en el país, corresponde a instituciones de carácter privado $(81 \%)$. El $70 \%$ de estos programas se ofrece en universidades, $29 \%$ en instituciones universitarias y solo $1 \%$ en instituciones técnicas profesionales.

En lo que respecta al posgrado, las cifras siguen la misma tendencia aunque de manera más pronunciada, pues se ofrecen en noventa y siete universidades $(84 \%)$ y diecinueve instituciones universitarias (16\%). El carácter privado o público es semejante, con un ligero incremento para las instituciones oficiales con un $12 \%$ de postgrado. El $88 \%$ restante se ofrece por instituciones de carácter privado.

Respecto a la modalidad de formación, se encuentra que tanto para el pregrado como para el posgrado, el $95 \%$ de los programas ofrecidos son presenciales. El $5 \%$ restante se distribuye entre programas virtuales y programas de formación a distancia. No obstante, esta cifra contrasta con un alto número de estudiantes para los programas virtuales y a distancia.

La distribución geográfica de los programas de pregrado y posgrado de psicología en el territorio nacional, es la siguiente:

En Antioquia, Atlántico, Bogotá y Valle del Cauca, se encuentra el 58,2\% de programas de pregrado y el $79,3 \%$ de los programas de posgrado del país (Tabla 1).

Tabla 1

Territorio nacional con mayor presencia de programas de psicología

\begin{tabular}{lcc}
\hline & Pregrado & Posgrado \\
\hline Antioquia & $19,4 \%$ & $32,8 \%$ \\
\hline Atlántico & $4,7 \%$ & $10,3 \%$ \\
\hline Bogotá D.C & $24,8 \%$ & $27,6 \%$ \\
\hline Valle del Cauca & $9,3 \%$ & $8,6 \%$ \\
\hline
\end{tabular}

Fuente: Elaboración propia.
En los departamentos de Bolívar, Boyacá, Caldas, Córdoba, Cundinamarca, Huila, Magdalena, Nariño, Risaralda y Santander, se encuentra el 27,3 \% de los programas de pregrado y el 20,9\% de posgrado (Tabla 2).

Tabla 2

Territorio nacional con presencia moderada de psicología

\begin{tabular}{lcc}
\hline & Pregrado & Posgrado \\
\hline Bolívar & $3,1 \%$ & $2,6 \%$ \\
\hline Boyacá & $1,6 \%$ & $0,9 \%$ \\
\hline Caldas & $1,6 \%$ & $0,9 \%$ \\
\hline Córdoba & $2,3 \%$ & $0,9 \%$ \\
\hline Cundinamarca & $1,6 \%$ & $2,6 \%$ \\
\hline Huila & $2,3 \%$ & $0,9 \%$ \\
\hline Magdalena & $1,6 \%$ & $1,7 \%$ \\
\hline Narińo & $3,1 \%$ & $0,9 \%$ \\
\hline Risaralda & $2,3 \%$ & $2,6 \%$ \\
\hline Santander & $7,8 \%$ & $6,9 \%$ \\
\hline Fuente: Elaboración propia. &
\end{tabular}

En los departamentos de Arauca, Cauca, Cesar, Chocó, Meta, Norte de Santander, Quindío, Sucre y Tolima, se encuentra tan solo una oferta de $14,9 \%$ de programas de psicología y una ausencia total de programas de posgrado (Tabla 3).

Tabla 3

Territorio nacional con presencia detenida de planes de psicología

\begin{tabular}{lcc}
\hline & Pregrado & Posgrado \\
\hline Arauca & $0,8 \%$ & - \\
\hline Cauca & $1,6 \%$ & - \\
\hline Cesar & $2,3 \%$ & - \\
\hline Chocó & $0,8 \%$ & - \\
\hline Meta & $0,8 \%$ & - \\
\hline Norte de Santander & $3,1 \%$ & - \\
\hline Quindío & $1,6 \%$ & - \\
\hline Sucre & $1,6 \%$ & - \\
\hline Tolima & $2,3 \%$ & - \\
\hline
\end{tabular}

Fuente: Elaboración propia.

Es interesante señalar cómo en las zonas donde hay mayor presencia del conflicto armado, hay menor presencia de los planes de formación académica de psicología. ¿Cuál será, entonces, la estrategia para que mejore-en estas zonas- la incidencia de la psicología en la calidad de vida de los individuos y en el bienestar social de la población?

Como se decía al comienzo, la consolidación de la psicología en Colombia es un hecho. El número de programas de pregrado ha alcanzado un máximo y los posgrados cuentan con una presencia mayor, lo que se traduce en un fortalecimiento de la comunidad.

$8<$ Universidad de San Buenaventura, Cali - Colombia 
En lo tocante a las inquietudes, estas atañen a la necesidad de vigilar el crecimiento de los pregrados, pues si este continúa de manera ininterrumpida, ello no resultaría conducente para el ejercicio de la profesión. Además, la calidad es un requisito que debe ir a la par con el desarrollo de los programas, aspecto que debería estar en la agenda de las instituciones encargadas del desarrollo de la psicología en Colombia. También es indispensable promover una formación y un ejercicio profesional éticos en el contexto colombiano.

Como hemos visto, la mayor parte de los programas pertenece al sector privado, frente a lo cual surgen algunos interrogantes: ¿cuál es el camino que permitirá un acercamiento entre la psicología y las políticas públicas del país? ¿Qué tipo de cooperación esperamos de estos planes de formación con organizaciones nacionales y con las insti- tuciones del Estado? Esperamos que la psicología colombiana continúe su desarrollo y siga buscando el bienestar de la sociedad, ahora llamada sociedad del postconflicto.

\section{Referencias}

Ardila, R. (1993). La Psicología en Colombia: contexto social e histórico. México: Editorial Trillas, S. A.

Melo, J. O. (1985). El desarrollo científico en Colombia. Memorias del Icfes.

Uricochea, F. (1991). Ciencia y educación superior: tendencias y perspectivas. In J. H. Cárdenas (Ed.), Doctorados (pp. 237262). Bogotá, Colombia: Tercer Mundo.

Vasco, C. E. (1984). Conclusiones. En ¿Es posible una psicología unificada? Serie Memorias de eventos científicos colombianos del ICFES. 


\title{
Editorial
}

\section{Overview of academic formation of psychologists in Colombia}

\author{
Julio César Ossa \\ Universidad de San Buenaventura Cali (Colombia) \\ Rebeca Puche-Navarro \\ Corporación Niñez y Conocimiento (Colombia)
}

This editorial is dedicated to psychology because we are aware of the fundamental role it plays in the well-being of a society. It is known that the Colombian society has been undermined by the armed conflict for a long time. Despite the wellness of Colombian psychology, there are some worrying signs which are worth taking into consideration. Each one can be easily deducted from the data obtained from its evolution.

The first Psychology academic program, which was the Institute of Applied Psychology founded in Universidad Nacional and directed by Mercedes Rodrigo (Ardila,1993), was created in Colombia in 1948. In 1962, the Psychology program in Pontificia Universidad Javeriana in Bogotá and the Psychological Counselling program in Universidad del Valle are created. In 1971-almost ten years after-the new psychology programs of Universidad de Los Andes in Bogota and the plan of Universidad del Norte in Barranquilla were developed.

Three periods, which characterize the evolution of Colombian psychology, can be identified. The first one has to do with the strengthening of the career (1948-1991), the second one with the expansive growth of the study plan in national territory (1992-2003), and the third one with the establishment (2004-2015).

In the 70 s, 6 new psychology programs were created. This reveals a higher presence of psychology in Colombia. The academic debates which took place in Psychology Conventions were characterized because of the staunch defense of a theoretical position which was circumscribed to a psychological orientation. It has been said that there were strong confrontations between behaviorists, psychoanalysts, and cognitive scientists among others.
By the middle of the 80s the number of psychology programs reaches 14. In 1984 a good share of the group of Colombian psychologists attend the Symposium named "Is a unified psychology possible?" According to Vasco (1984), the aim of this symposium was to "discern the comparative advantages between two or more theories which deal with the same observable regularity" (p. 195). Since this is general knowledge, the simplifying purpose had no result (psychological theories were not cut by the blade of Ockham). Instead of this, more psychology orientations were imported, each one with theoretical views, conceptual frameworks, and clearly differentiated methodologies.

The peak and growth of psychology programs is not particular but it turns out to be illustrative of a situation which concerns all the Colombian University. Changes in the 70s correspond to the modernization processes of a country whose conditions require a stronger university project fulfilling its needs. It is a country in an accelerated urbanization process and with government reforms aimed at the necessary modernization, changes in the university respond to this process (Melo, 1985; Uricochea, 1991). In this context the evolution of psychology is simply an illustrative case of this global process.

The second period is related to the expansive growth of the study plans in the national territory. Between 1992 and 2003, psychology programs rise from 16 to 98 in Colombia. This expansion growth is registered as the highest that academic psychology has had in Colombia.

The third period has a certain establishment regarding new undergraduate programs. Between 2003 and 2014, only 29 psychology programs were created, which marks 
a difference with the previous period. Even though in the second period the emergence of postgraduate psychology programs had started, it was in the third period that they are consolidated.

Currently, What can be said about academic formation of psychologists in Colombia? Let us begin with some figures regarding the offer of formation programs. According to the National System of Information of Superior Education (SNIES, 2015) Colombia has 129 psychology undergraduate programs and 116 postgraduate programs.

The academic landscape of psychology in Colombia shows that most university education in the country corresponds mainly (81\%) to private institutions. $70 \%$ of these programs are offered in Universities, 29\% in university institutions and only $1 \%$ in professional technical institutions.

Figures regarding postgraduate programs have the same tendency in a more noticeable way. These are in 97 universities (84\%) and 19 in university institutions $(16 \%)$. The private and public sector is similar with a slight increase for official institutions which reach a $12 \%$ of postgraduate programs and the remaining $88 \%$ is offered by private institutions.

The formation method for both the undergraduate and postgraduate programs is $95 \%$ classroom-based and the remaining $5 \%$ is distributed in virtual and distance formation programs. This figure contrasts with an impressively high number of students for virtual and distance formation programs.

The geographical distribution of the undergraduate and postgraduate psychology programs in national territory is as follows:

In Antioquia, Atlántico, Bogotá and Valle del Cauca we find $58.2 \%$ of undergraduate programs and $79.3 \%$ of the postgraduate programs in the country.

Table 1

National territory with the highest presence of psychology programs

\begin{tabular}{lcc}
\hline & Undergraduate & Postgraduate \\
\hline Antioquia & $19.4 \%$ & $32.8 \%$ \\
\hline Atlántico & $4.7 \%$ & $10.3 \%$ \\
\hline Bogotá D.C & $24.8 \%$ & $27.6 \%$ \\
\hline Valle del Cauca & $9.3 \%$ & $8.6 \%$ \\
\hline
\end{tabular}

In the departments of Bolívar, Boyacá, Caldas, Córdoba, Cundinamarca, Huila, Magdalena, Narińo, Risaralda and Santander we find $27.3 \%$ of undergraduate programs and $20.9 \%$ of postgraduate programs.
Table 2

National territory with moderate presence in psychology

\begin{tabular}{lcc}
\hline & Undergraduate & Postgraduate \\
\hline Bolívar & $3.1 \%$ & $2.6 \%$ \\
\hline Boyacá & $1.6 \%$ & $0.9 \%$ \\
\hline Caldas & $1.6 \%$ & $0.9 \%$ \\
\hline Córdoba & $2.3 \%$ & $0.9 \%$ \\
\hline Cundinamarca & $1.6 \%$ & $2.6 \%$ \\
\hline Huila & $2.3 \%$ & $0.9 \%$ \\
\hline Magdalena & $1.6 \%$ & $1.7 \%$ \\
\hline Nariño & $3.1 \%$ & $0.9 \%$ \\
\hline Risaralda & $2.3 \%$ & $2.6 \%$ \\
\hline Santander & $7.8 \%$ & $6.9 \%$ \\
\hline
\end{tabular}

In the department of Arauca, Cauca, Cesar, Chocó, Meta, Norte de Santander, Quindío, Sucre and Tolima we only find an offering of $14.9 \%$ psychology programs and a total lack of postgraduate programs.

Table 3

National territory with ceased presence in psychology plans

\begin{tabular}{lcc}
\hline & Undergraduate & Postgraduate \\
\hline Arauca & $0.8 \%$ & - \\
\hline Cauca & $1.6 \%$ & - \\
\hline Cesar & $2.3 \%$ & - \\
\hline Chocó & $0.8 \%$ & - \\
\hline Meta & $0.8 \%$ & - \\
\hline Norte de Santander & $3.1 \%$ & - \\
\hline Quindío & $1.6 \%$ & - \\
\hline Sucre & $1.6 \%$ & - \\
\hline Tolima & $2.3 \%$ & - \\
\hline
\end{tabular}

It is interesting to point out that the areas where there is a higher presence of the armed conflict, there is also a lower presence of the academic formation plans for psychology. What would the strategy be to improve-in these areas-the incidence of psychology in the quality of life of individuals and the social well-being of the population?

As said initially, the consolidation of psychology in Colombia is a fact, the number of undergraduate programs has reached a peak and the postgraduate programs have a higher presence, which shows a strengthening of the community. Concerns create the need to watch the growth of undergraduate programs; if this growth persists in the same way, this would not be conductive for the practice of the profession. Moreover, quality is a requirement which must be at the same standard as the development of the programs and this point would have to be in the agenda of the institutions in charge of the development of psychology in Colombia. It is also indispensable to

$12 \&$ Universidad de San Buenaventura, Cali - Colombia 
promote a formation and an ethical professional exercise in the Colombian context.

Since most programs are in the private sector, there are some questions regarding this. Which is the correct path to allow an approach between psychology and public policies of Colombia? What kind of cooperation should we expect form these formation plans with national organizations and government institutions? We hope that Colombian psychology continues with its development and that it keeps seeking the well-being of a society which is now referred to as the post conflict society.

\section{References}

Ardila, R. (1993). La Psicología en Colombia: contexto social e histórico. México: Editorial Trillas, S. A.

Melo, J. O. (1985). El desarrollo científico en Colombia. Memorias del ICFES.

Uricochea, F. (1991). Ciencia y educación superior: tendencias y perspectivas. In J. H. Cárdenas (Ed.), Doctorados (pp. 237262). Bogotá, Colombia: Tercer Mundo.

Vasco, C. E. (1984). Conclusiones. En ¿Es posible una Psicología Unificada? Serie Memorias de eventos científicos colombianos del ICFES. 


\title{
Editorial
}

\section{Panorama da formação acadêmica dos psicólogos na Colômbia}

\author{
Julio César Ossa \\ Universidad de San Buenaventura, Cali- Colômbia \\ Rebeca Puche-Navarro \\ Corporación Niñez y Conocimiento
}

Dedicamos este editorial à Psicologia, porque entendemos o papel fundamental desta disciplina no bem-estar da sociedade. Não é nenhuma novidade que a sociedade colombiana tem sido prejudicada pelo conflito por um longo tempo. Embora atualmente a psicologia está en boa saúde há alguns sinais preocupantes de que podé valer a pena considerar. A um e outro pode ser facilmente inferida a partir dos números que lança sua evolução.

Em 1948 foi criado o primeiro programa acadêmico de Psicologia, na Colômbia, é o Instituto de Psicologia Aplicada da Universidade Nacional fundada sob a liderança da Mercedes Rodrigo (Ardila, 1993). Em 1962 aparece o programa de psicologia da Pontificia em Bogotá e o programa de Aconselhamento Psicológico da Universidade del Valle em Cali. Em 1971, quase dez anos depois, foram criados novos programas de psicologia na Universidade dos Andes, em Bogotá eo plano da Universidad del Norte em Barranquilla.

Podemos identificar três períodos que caracterizaram a evolução do psychology colombiano. O primeiro tem a ver com o reforço da carreira (1948-1991) o segundo com o crescimento expansivo do currículo no país (1992-2003) e do período de liquidação terceiro (2004-2015). Nos anos 70 foram criados 6 novos programas de psicologia, que mostram uma maior presença de psicologia na Colômbia. Os debates acadêmicos que ocorreram nas Convençóes de Psicologia foram caracterizados pela defesa firme de uma posiçáo teórica que estava confinado a uma orientação psicológica. Há mesmo uma conversa de intensos debates entre os behavioristas, cognitivas, psicanalíticos, entre outros.
Em meados dos anos 80 o número de programas de psicologia atinge 14. Em 1984, grande parte do grupo de psicólogos colombianos que frequentam o simpósio intitulado Can uma psicologia unificada? De acordo com Vasco (1984) o objetivo deste simpósio foi o de "discernir as vantagens comparativas entre duas ou mais teorias que tratam com a mesma regularidade observável" (p. 195). Como é do conhecimento geral que finalidade a simplificação não teve sucesso (teorias psicológicas não foram cruzados pela navalha de Ockham). Em vez são importados mais orientação em psicologia cada um com aspectos teóricos, marcos conceituais e metodologias distintas.

O surgimento e crescimento de programas de psicologia, não é particular senão que ilustrativo de uma situaçáo que diz respeito a toda a universidade colombiana. $\mathrm{Mu}-$ danças na década de 70 se relacionam com a modernização de um país que, nessas condições, necessita de um projeto universitário mais forte que responda às suas necessidades. É um país em um rápido processo de urbanização e con umas reformas do Estado destinadas a uma modernização necessária, os mudanças na universidade responder a esse processo (Melo, 1985; Uricochea, 1991). Nesse contexto, a evolução da psicologia é simplesmente um exemplo deste processo global.

O segundo período refere-se ao crescimento expansivo do currículo no país. De 1992 a 2003, ele está se movendo de 16-98 programas de psicologia na Colômbia. Este crescimento expansionista como o maior que teve psicologia acadêmica na Colômbia é gravado.

O terceiro trimestre estabilizou um pouco em termos de novos cursos de graduação. Entre 2003 e 2014 foram 
criados apenas 29 programas em psicologia, que marca uma diferença em relação ao período anterior. Embora tenha iniciado a ascensão de programas de pós-graduaçáo no segundo período, no último período eles estão consolidadas.

Mas agora ¿que você pode dizer sobre a formação acadêmica dos psicólogos na Colômbia? Vamos começar com alguns números relativos ao fornecimento de programas de treinamento. De acordo com o Sistema Nacional de Informação para o Ensino Superior (SNIES, 2015) Colômbia tem 129 programas de psicologia de graduação e pós-graduação 116.

A paisagem acadêmica de psicologia na Colômbia mostra que como grande parte da educação universitária no país, a maioria (81\%) são instituiçôes privadas. 70\% destes programas são oferecidos em universidades, $29 \%$ nas universidades e apenas $1 \%$ em instituiçôes técnicos vocacionais.

Em relação à pós-graduação números seguem a mesma tendência forma ainda mais acentuada como oferecido em 97 universidades (84\%) e 19 universidades (16\%). A natureza privada ou pública é semelhante com um ligeiro aumento para as instituiçóes oficiais à medida que atingem $12 \%$ de pós-graduação e os $88 \%$ restantes são oferecidos por instituiçôes privadas.

Quanto ao tipo de treinamento é que tanto para graduação e pós-graduação, 95\% dos programas oferecidos são rosto; os restantes $5 \%$ é dividido entre os programas virtuais e programas de ensino à distância. Esse número contrasta contudo com um elevado número impressionante de estudantes para programas virtuais e à distância.

A distribuição geográfica dos programas de graduação e pós graduaçáo em psicologia no país é a seguinte:

1. Em Antioquia, Atlántico, Bogotá e Valle del Cauca é de $58,2 \%$ dos cursos de graduaçáo e $79,3 \%$ dos programas de pós-graduação no país.

\section{Tabela 1.}

Mais presença nacional de programas de psicologia

\begin{tabular}{lcc}
\hline & Graduaçáo & pós-graduaçáo \\
\hline Antioquia & $19.4 \%$ & $32.8 \%$ \\
\hline Atlántico & $4.7 \%$ & $10.3 \%$ \\
\hline Bogotá D.C & $24.8 \%$ & $27.6 \%$ \\
\hline Valle del Cauca & $9.3 \%$ & $8.6 \%$ \\
\hline
\end{tabular}

2. Nos departamentos de Bolívar, Boyacá, Caldas, Córdoba, Cundinamarca, Huila, Magdalena, Nariño,
Risaralda e Santander é de 27,3\% dos cursos de graduação e 20,9\% dos programas de pós-graduação.

Tabela 2.

Presença nacional moderada de psicologia

\begin{tabular}{lcc}
\hline & Graduaçáo & pós-graduaçáo \\
\hline Bolívar & $3.1 \%$ & $2.6 \%$ \\
\hline Boyacá & $1.6 \%$ & $0.9 \%$ \\
\hline Caldas & $1.6 \%$ & $0.9 \%$ \\
\hline Córdoba & $2.3 \%$ & $0.9 \%$ \\
\hline Cundinamarca & $1.6 \%$ & $2.6 \%$ \\
\hline Huila & $2.3 \%$ & $0.9 \%$ \\
\hline Magdalena & $1.6 \%$ & $1.7 \%$ \\
\hline Narińo & $3.1 \%$ & $0.9 \%$ \\
\hline Risaralda & $2.3 \%$ & $2.6 \%$ \\
\hline Santander & $7.8 \%$ & $6.9 \%$ \\
\hline
\end{tabular}

3. Nos departamentos de Arauca, Cauca, Cesar, Chocó, Meta, Norte de Santander, Quindío, Sucre e Tolima é apenas uma oferta de $14,9 \%$ dos programas de psicologia e uma total ausência de programas de pós-graduação.

Tabela 3.

Presença nacional preso de psicologia

\begin{tabular}{lcc}
\hline & Graduaçáo & pós-graduaçáo \\
\hline Arauca & $0.8 \%$ & - \\
\hline Cauca & $1.6 \%$ & - \\
\hline Cesar & $2.3 \%$ & - \\
\hline Chocó & $0.8 \%$ & - \\
\hline Meta & $0.8 \%$ & - \\
\hline Norte de Santander & $3.1 \%$ & - \\
\hline Quindío & $1.6 \%$ & - \\
\hline Sucre & $1.6 \%$ & - \\
\hline Tolima & $2.3 \%$ & - \\
\hline
\end{tabular}

Curiosamente, em áreas onde uma elevada proporçáo de conflito armado há menos presença dos planos de formação acadêmica em psicologia. ntáo, ¿qual será a estratégia para melhorar estas áreas--em a incidência de psicologia na qualidade de vida dos indivíduos eo bem-estar social?

Como disse inicialmente a consolidação da psicologia na Colômbia que é um fato, o número de cursos de graduação atingiu o pico e pós-graduação têm uma presença maior, resultando em um fortalecimento da comunidade. As preocupaçóes sobre a necessidade de acompanhar o crescimento de graduaçáo; Se este crescimento continua, desta forma, não é propício para o exercício da profissão. Além disso, a qualidade é uma exigência que deve ir de mãos dadas com o desenvolvimento de programas e este

$16 \&$ Universidad de San Buenaventura, Cali - Colombia 
ponto deve estar na agenda das instituiçôes responsáveis pelo desenvolvimento da psicologia na Colômbia. É também essencial para promover um treinamento e prática ética no contexto colombiano.

Como vimos a maioria dos programas pertence do sector privado, em comparação assim algumas questóes surgem Qual é o caminho que permitirá uma aproximação entre psicologia e políticas públicas do país. Que tipo de cooperaçáo que esperar destes programas de formaçáo com organizaçóes nacionais e instituiçóes do Estado? Esperamos que a psicologia colombiano prosseguir o seu desenvolvimento e para continuar a procurar o bem da sociedade agora chamada sociedade pós-conflito.

\section{Referências}

Ardila, R. (1993). La Psicología en Colombia: contexto social e histórico. México: Editorial Trillas, S. A.

Melo, J. O. (1985). El desarrollo científico en Colombia. Memorias del ICFES.

Uricochea, F. (1991). Ciencia y educación superior: tendencias y perspectivas. In J. H. Cárdenas (Ed.), Doctorados (pp. $237-$ 262). Bogotá, Colombia: Tercer Mundo.

Vasco, C. E. (1984). Conclusiones. En ¿Es posible una Psicología Unificada? Serie Memorias de eventos científicos colombianos del ICFES. 